\title{
Homotryblium-dominated Eocene dinoflagellate cyst assemblages from Middle Miocene (Badenian) glauconitic sands at Lipowiec (Roztocze, SE Poland)
}

\author{
Przemysław GEDL ${ }^{1, *}$
}

\author{
1 Polish Academy of Sciences, Institute of Geological Sciences, Senacka 1, 31-002 Kraków, Poland
}

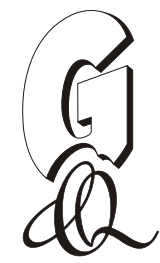

Gedl, P., 2016. Homotryblium-dominated Eocene dinoflagellate cyst assemblages from Middle Miocene (Badenian) glauconitic sands at Lipowiec (Roztocze, SE Poland). Geological Quarterly, 60 (2): 461-472, doi: 10.7306/gq.1289

\begin{abstract}
A section over $20 \mathrm{~m}$ thick of the basal Middle Miocene succession exposed at Lipowiec (Roztocze, SE Poland) was studied for palynology. Thirteen samples were collected from quartz and glauconitic-quartz sands and thin clay layers. Sand samples were barren but clay samples yielded dinoflagellate cysts. Their assemblages consist of reworked Paleogene specimens dominated by the Homotryblium floripes complex ( $H$. floripes and morphologically similar $H$. plectilum and $H$. vallum). The presence of reworked Paleogene specimens indicates intense erosion of marine Paleogene strata during initial stages of the Middle Miocene transgression at Roztocze. Analysis of stratigraphical ranges of reworked dinoflagellate cysts and comparison with their occurrences in known epicontinental Paleogene sites of SE Poland suggest an Upper Eocene age of the washed-out strata. The taxonomic composition of the assemblages described suggests that the Upper Eocene deposits accumulated in a near-shore, lagoonal embayment characterized presumably by oligotrophic waters of slightly increased salinity. A high proportion of the Homotryblium floripes complex is also characteristic of reworked assemblages found in younger Miocene strata of neighbouring exposures in Roztocze, which indicates widespread Eocene lagoonal environments in this part of Roztocze. Coeval Eocene strata from the eastern part of Roztocze and from the Carpathian Foredeep show different taxonomic compositions suggesting varied sedimentary settings during Eocene transgression in this region. These differences reflect variable amounts of freshwater influence resulting in a range of environments that ranged from oligotrophic to brackish.
\end{abstract}

Key words: Eocene, Miocene, reworking, palaeoenvironment, Roztocze, SE Poland.

\section{INTRODUCTION}

Eocene and Oligocene marine strata were formerly widely distributed in SE Poland covering a part of the Carpathian foreland that now forms the Roztocze hills and the eastern part of the Carpathian Foredeep. Most of them were removed by post-Rupelian erosion that left only a few sites with preserved deposits of these ages (e.g., Buraczyński and Krzowski, 1994; Gaździcka, 1994; Gedl, 2000, 2012, 2014, 2015; Myśliwiec and Śmist, 2006). This makes reconstruction of Eocene and Oligocene palaeogeography in SE Poland, and of their palaeoenvironmental characteristics, difficult. In such cases, reworked Paleogene microfossils, dinoflagellate cysts in particular, which occur in Miocene strata of the Carpathian Foredeep, are helpful. Reworked dinoflagellate cysts have been described from several Miocene sections, indicating a much wider extent of Eocene and Oligocene epicontinental seas in SE Poland than could be inferred from the basis of preserved Paleogene sites (Gedl, 2012).

\section{*E-mail: ndgedl@cyf-kr.edu.pl}

Received: February 11, 2016; accepted: March 30, 2016; first published online: April 11, 2016
Middle Miocene succession of Roztocze appears to be particularly rich in reworked Paleogene, particularly Eocene, dinoflagellate cyst species. Frequent reworked forms, commonly outnumbering Miocene specimens, have been described from Upper Badenian deposits that rest upon the evaporitic horizon at Józefów (Gedl, 2012, 2016).

Further discoveries of reworked Paleogene dinoflagellate cysts in the Lower Badenian strata of Roztocze, presented in this paper, indicate expansion of the time interval during which the Paleogene cover underwent erosion. I provide stratigraphical analysis of the assemblages to allow their dating, and qualitative analysis to make palaeoenvironmental reconstructions of now non-existing Eocene strata.

\section{GEOLOGICAL BACKGROUND}

The Carpathian Foredeep Basin developed as a foreland basin at the front of the northwards-migrating Carpathian orogen. It stretches along the front of Carpathians from Austria to Romania, a distance of over $1300 \mathrm{~km}$. In the Polish part (Fig. $1 \mathrm{~A})$, the Carpathian Foredeep is divided into inner and outer parts. The inner part is nowadays covered by overthrusted Carpathian nappes, or occurs as narrow belts of folded strata at the front of the Carpathians. It includes the Lower (mainly continental) and Middle Miocene (Badenian and Sarmatian depos- 


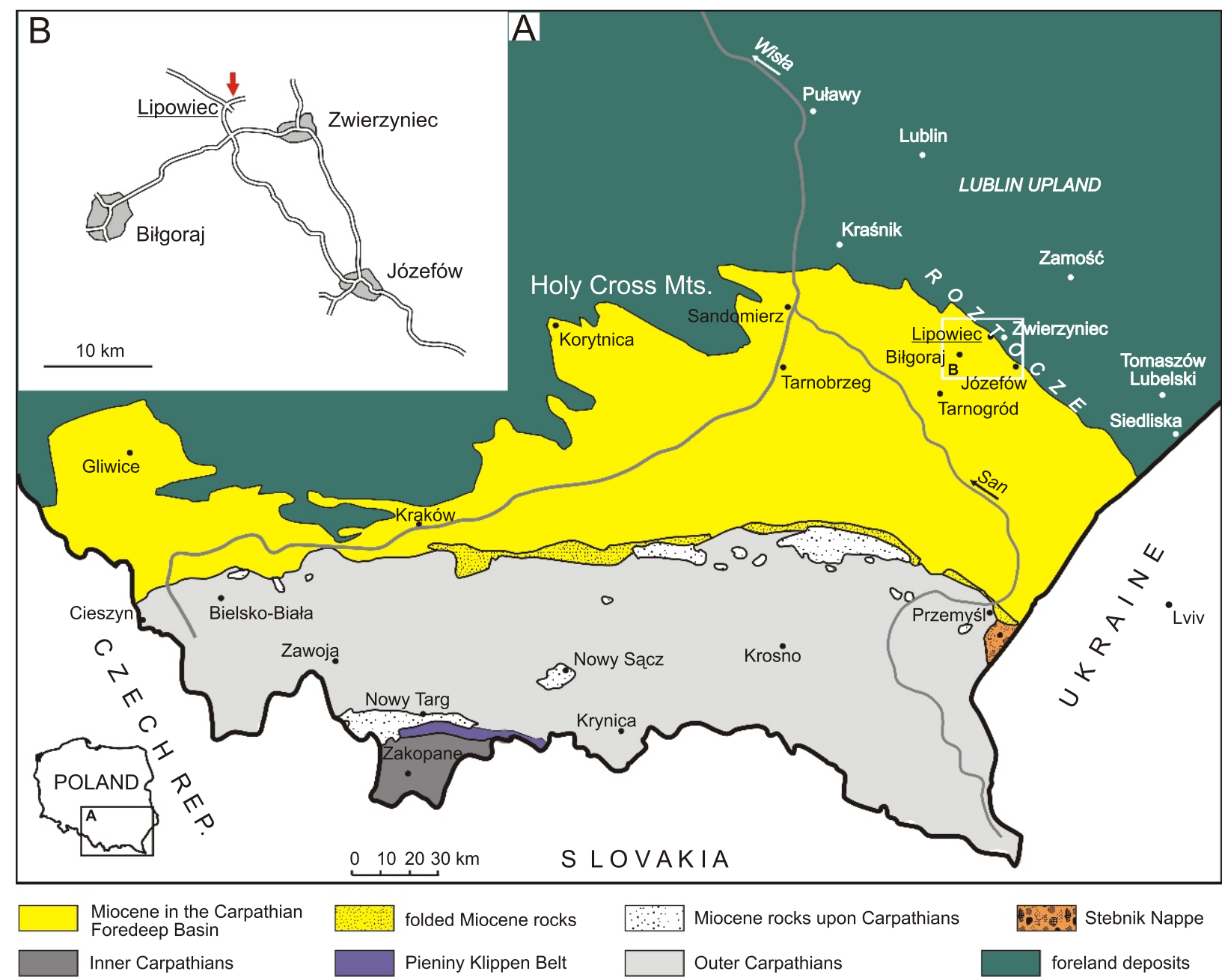

Fig. 1. Location of the site studied and geology of the study area

A - geological sketch of SE Poland showing positions of main geological structures and localities mentioned in the text (based on Żytko et al., 1989, from Oszczypko, 1996); B - location of the exposure at Lipowiec (arrowed)

its), which are marine. The outer part of the Carpathian Foredeep is filled with Badenian and Sarmatian marine strata that reach up to $2000 \mathrm{~m}$ in thickness, and $5000 \mathrm{~m}$ in the Ukrainian part (for details see e.g., Ney et al., 1974; Kotlarczyk, 1985; Oszczypko et al., 2006).

The Miocene sequence of the outer part of the Carpathian Foredeep is associated with a marine transgression that started in early phases of the Badenian (i.e., Langhian). It traditionally comprises a tripartite division: pre-evaporitic, evaporitic (chemical deposits) and post-evaporitic strata (numerous informal lithostratigraphic divisions that are difficult to correlate). The stratigraphy of this sequence is based mainly on planktonic foraminifera and calcareous nannoplankton, which show that the bulk of the rocks may be correlated with the Middle Miocene NN5 to NN9 calcareous nannoplankton zones and the M5 to M8-11 planktonic foraminifera zones (e.g., Garecka et al., 1996; Garecka and Jugowiec, 1999; Olszewska, 1999).

A similar, tripartite division can be applied to the Miocene succession in the Roztocze area, which represents a marginal facies of the Carpathian Foredeep Basin. However, this succession, due to its unique tectonic position, shows a different development than its counterparts in central areas of the sedimentary basin. Roztocze is an uplifted area (in relation to the Carpathian Foredeep to the south) in the southern part of the Lublin Upland; its longitudinal structure stretches NW-SE from Kraśnik in Poland to Lviv in Ukraine (Fig. 1A). Due to its uplifted position, the Middle Miocene (Badenian) transgression in Roztocze led to accumulation of thin (merely 30-40 m thick compared to over $2.000 \mathrm{~m}$ in the basinal part) shallow-marine coarse siliciclastic and organodetrital deposits (Fig. 2). They rest upon Upper Cretaceous strata with locally preserved marine Paleogene. Locally, in the base of the Middle Miocene succession, continental phytogenic deposits of uncertain, presumably Lower Miocene (Karpatian, i.e., uppermost Burdigalian) age occur (e.g., Jankowski et al., 2014).

Both the marine Paleogene and continental strata underwent significant erosion during and after uplift movements responsible for formation of the Roztocze structure. Erosion led to almost complete removal of these strata. Most complete sections of the epicontinental marine Eocene in the Carpathian foreland are known from the Sołokija Graben in Roztocze, and from the Łukowa-4 borehole (Tarnogród vicinity) in the 


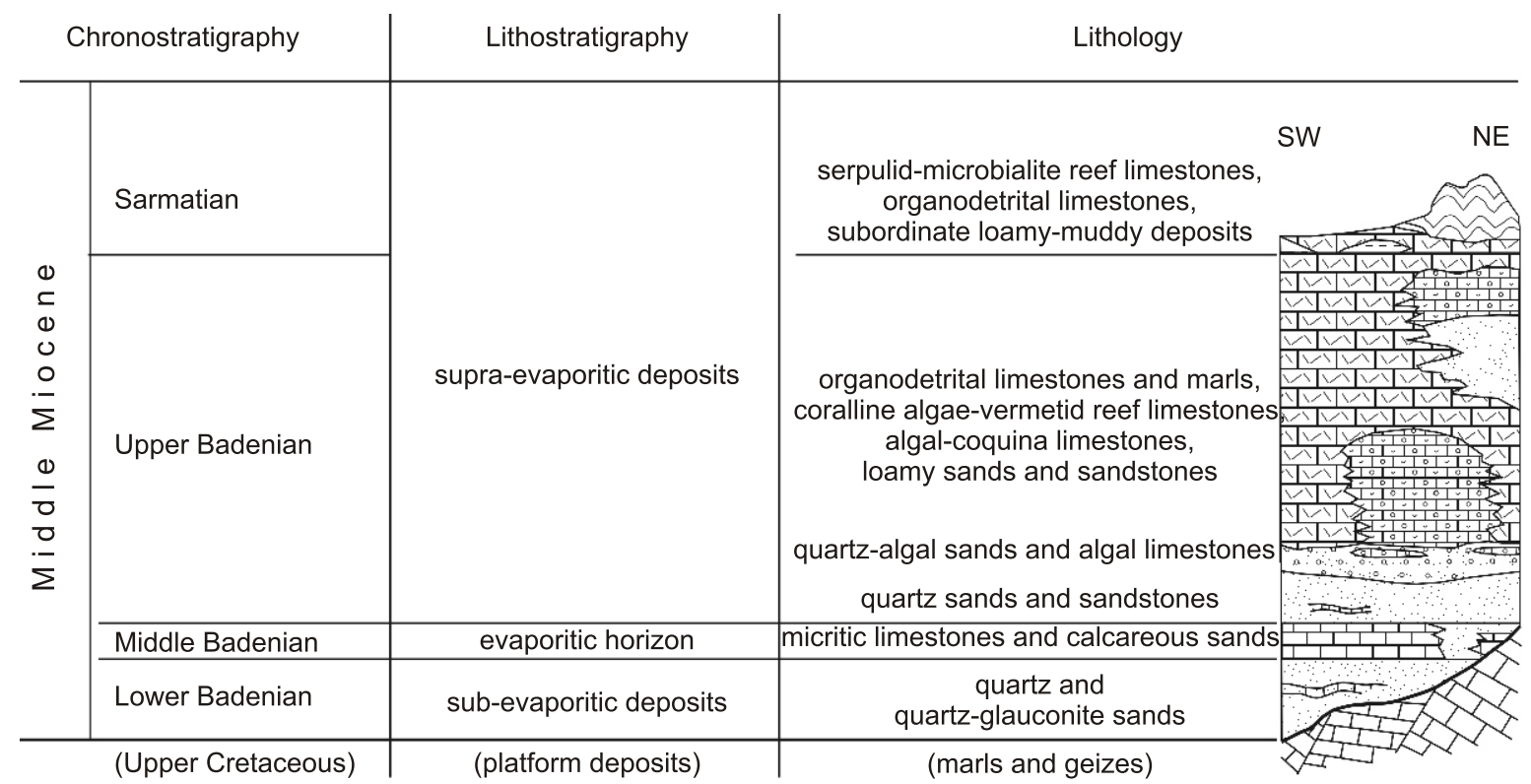

Fig. 2. Synthetic scheme of lithostratigraphy and lithology of Miocene strata in the Polish part of Roztocze (after Musiał, 1987, from Wysocka, 2002)

Carpathian Foredeep. They represent the Bartonian-Lower Priabonian in the Sołokija Graben (Gaździcka, 1994; Gedl, 2014), and the Priabonian in the Łukowa-4 borehole (Gedl, 2015). Isolated sandy deposits near Tomaszów Lubelski, which form a residual hill, are believed to represent the Paleogene, although no palaeontological evidence has been found so far (Buraczyński and Krzowski, 1994).

The presence of Eocene marine strata at Roztocze and in the Carpathian Foredeep suggests that the uplift of the Roztocze structure started in the Oligocene or later. Jankowski and Margielewski (2014) correlated phytogenic deposits of Roztocze (Siemiatycze, Rawa Ruska) and the neighbouring part of the foredeep basin (Tarnogród), and concluded that uplift movements began not earlier than after their accumulation in the Karpatian (Early Miocene; this view requires further studies because at least some of phytogenic deposits of the Carpathian Foredeep Basin may be of Oligocene age; Myśliwiec and Śmist, 2006; Gedl, 2015). According to Jankowski and Margielewski (2014), Roztocze was already an uplifted structure during deposition of organodetrital strata - dated to the Late Badenian according to e.g., Szczechura (1982), Musiał (1987), Wysocka (2002), and the Sarmatian-Pannonian according to Czepiec (1996), and Jankowski and Margielewski (2015), who treated Badenian microfossils as reworked, although no list of younger microfossils was given by the latter.

\section{MATERIAL}

Material for this study comes from sandy Miocene strata that occur in a scarp of a steep topographic ridge of the Roztocze hills (Fig. 1B). Samples were collected from an exposure and a shallow borehole located a few metres north of the road that leads from the village of Lipowiec to the top of a local hill at the hamlet of Lipowiec-Góry (GPS coordinates: N50³7.792', E022 $\left.{ }^{\circ} 52.172^{\prime}\right)$. This exposure, over $10 \mathrm{~m}$ high, was described and illustrated in detail by Margielewski (in Krapiec et al., 2010: point 2) and Jankowski and Margielewski
(2014). It represents basal part of the Badenian (Middle Miocene) transgressive succession at Roztocze (the Cretaceous substrate was penetrated by drilling almost $9 \mathrm{~m}$ below the bottom of the exposure; see Jankowski and Margielewski, 2014: fig. 4). The higher part of the sandy succession is exposed some $100 \mathrm{~m}$ north, on the same side of the road; its topmost part consists of coralline algal limestone that forms the top of the hills.

Strata exposed consist of white, beige and rusty, non-calcareous quartz sand that predominates in the upper part, and greenish non-calcareous quartz sand with glauconite in the basal part (Fig. 3). A few dark brown non-calcareous muddy clay layers occur. A hand-drilled borehole penetrated the underlying part of the succession, down to a depth of almost $5 \mathrm{~m}$ (i.e., it stopped ca. $4 \mathrm{~m}$ above the base of the Miocene succession; Fig. 3). This part consists of dominating greenish, fine-grained non-calcareous glauconitic-quartz loamy sands interlayered with rusty coarse-grained quartz sand layers. A few pale greenish clay layers are present. A total of thirteen samples was taken from the exposure and core. Seven samples were taken from clay layers, three samples were taken from loamy sand with glauconite from the lowermost drilled interval, and three samples from quartz sand from the upper part of the exposure (Fig. 3).

\section{METHODS}

The samples were processed in the micropalaeontological laboratory of the Institute of Geological Sciences, Polish Academy of Sciences, Research Centre in Kraków. The quantity of rock processed was variable, depending on the lithology: $30 \mathrm{~g}$ for clay samples and $500 \mathrm{~g}$ for sand samples. Samples were washed in water, and the fraction between 10 and $250 \mu \mathrm{m}$ (sieved at 250 and $10 \mu \mathrm{m}$ on a nylon mesh) was treated with $40 \%$ hydrofluoric acid (HF), heavy-liquid $\left(\mathrm{ZnCl}_{2}+\mathrm{HCl}\right.$; density $2.0 \mathrm{~g} \cdot \mathrm{cm}^{-3}$ ) separation. The residue was sieved again at $10 \mu \mathrm{m}$ on a nylon mesh. No nitric acid $\left(\mathrm{HNO}_{3}\right)$ treatment was applied. 

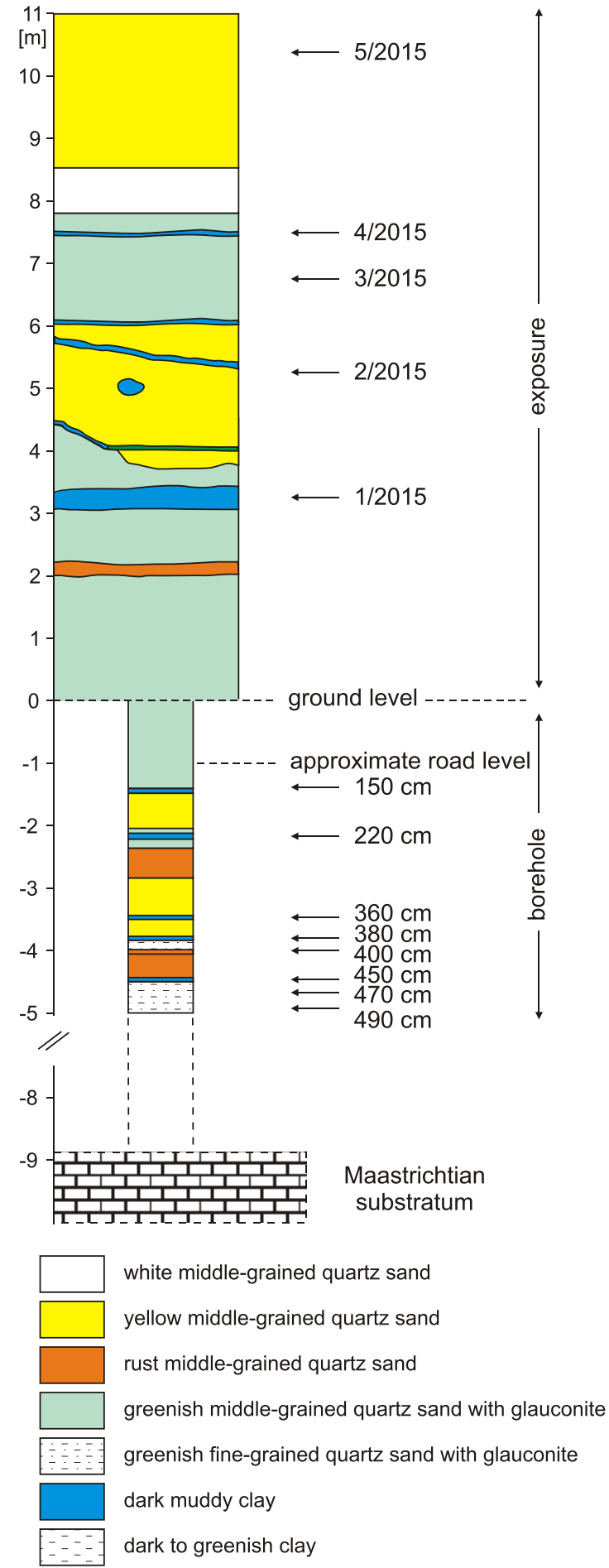

Fig. 3. Lipowiec exposure and borehole with position of samples collected (exposure lithology after Krapiec et al., 2010)

Two palynological slides were made from each sample using glycerine jelly as a mounting medium. All dinoflagellate cysts were counted from both slides using a Carl Zeiss Axiolab microscope. Photographs of aquatic palynomorphs were taken using a Sony DSC-S75 camera and Carl Zeiss Achroplan x100 oil lens. The rock samples, palynological residues and slides are stored in the collection of the Institute of Geological Sciences, Polish Academy of Sciences, Research Centre in Kraków.

\section{RESULTS}

Samples from quartz sand (5/2015) and quartz-glauconitic sand $(3 / 2015)$ were barren. Loamy glauconitic sand $(400,470$ and $490 \mathrm{~cm}$ ) yielded organic debris composed of very fine particles of black and dark brown phytoclasts and pale remains of land plant tissues. Rare bisaccate pollen grains occur; no dinoflagellate cysts have been found.

Clay samples yielded higher amounts of palynological matter, which, except for sample $1 / 2015$, includes aquatic palynomorphs. The latter are marine dinoflagellate cysts present in all samples, and thin-walled spherical forms of uncertain origin found in the sample from $220 \mathrm{~cm}$ depth; their distribution is shown in Figure 4. Dinoflagellate cysts are pale-coloured, their wall structure shows no traces of increased maturity. However, they are commonly preserved as fragments (particularly large chorate forms such as Areosphaeridium; Fig. 5P, X) or they show traces of mechanical damage. The dinoflagellate cysts are illustrated in Figures 5 to 7.

The sample from $450 \mathrm{~cm}$ depth yielded infrequent fragments of undeterminable dinoflagellate cysts, some of these presumably being Cleistosphaeridium. The remaining clay samples yielded assemblages that consist of frequent Homotryblium representing a morphological complex $(H$. floripes, $H$. plectilum, $H$. vallum; see de Verteuil and Norris, 1996: p. 22; Fig. 5A-O, Q-S) associated with various proportions of other species (Fig. 4). The proportion of Homotryblium in these samples is as follows: $51 \%(380 \mathrm{~cm}), 96 \%(360 \mathrm{~cm}), 69 \%(220 \mathrm{~cm})$, $88 \%(150 \mathrm{~cm}), 52 \%(2 / 2015)$, and $100 \%(4 / 2015)$.

Taxa other than the dominant Homotryblium are Glaphyrocysta, Cleistosphaeridium, Heterosphaeridium, and Membra-

\begin{tabular}{|c|c|c|c|c|c|c|c|c|}
\hline 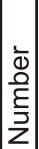 & + & \begin{tabular}{l}
$\varepsilon$ \\
$\mathcal{E}$ \\
0 \\
0 \\
\multirow{\gamma}{*}{}
\end{tabular} & \begin{tabular}{|l|}
$\varepsilon$ \\
0 \\
0 \\
0 \\
$m$
\end{tabular} & 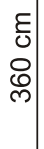 & 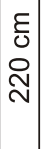 & 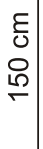 & 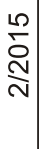 & $\frac{10}{\delta}$ \\
\hline 1 & Cleistosphaeridium placacanthum & $?$ & 5 & 1 & 1 & 2 & 3 & \\
\hline 2 & Glaphyrocysta sp. & & 2 & & & & & \\
\hline 3 & Glaphyrocysta cf. semitecta & & 2 & & & & & \\
\hline 4 & Homotryblium floripes & & 22 & 31 & 19 & 15 & 12 & 12 \\
\hline 5 & Homotryblium plectilum & & 13 & 12 & 10 & 6 & & 5 \\
\hline 6 & ?Areosphaeridium michoudii & & 3 & & 2 & & 2 & \\
\hline 7 & Cleistosphaeridium sp. A & & 4 & & 1 & & & \\
\hline 8 & Glaphyrocysta semitecta & & 3 & & 2 & 1 & & \\
\hline 9 & Heterosphaeridium sp. A & & 8 & & & & & \\
\hline 10 & Pentadinium? sp. & & 1 & & & & & \\
\hline 11 & Membranophoridium aspinatum & & 1 & & & & & \\
\hline 12 & Membranophoridium connectum & & 1 & & 4 & & 1 & \\
\hline 13 & Adnatosphaeridium multispinosum & & 1 & & 1 & & & \\
\hline 14 & Cleistosphaeridium cf. placacanthum & & 2 & & & 1 & 3 & \\
\hline 15 & Homotryblium vallum & & & 5 & & 1 & & \\
\hline 16 & Spiniferites pseudofurcatus & & & 1 & 1 & & & \\
\hline 17 & Enneadocysta sp. & & & & 1 & & & \\
\hline 18 & Homotryblium aculeatum & & & & 1 & & & \\
\hline 19 & spherical palynomorphs & & & & 42 & & & \\
\hline 20 & Areosphaeridium diktyoplokum & & & & & & 1 & \\
\hline 21 & Glaphyrocysta microfenestrata & & & & & & 1 & \\
\hline
\end{tabular}

Fig. 4. Dinoflagellate cyst occurrence at Lipowiec 


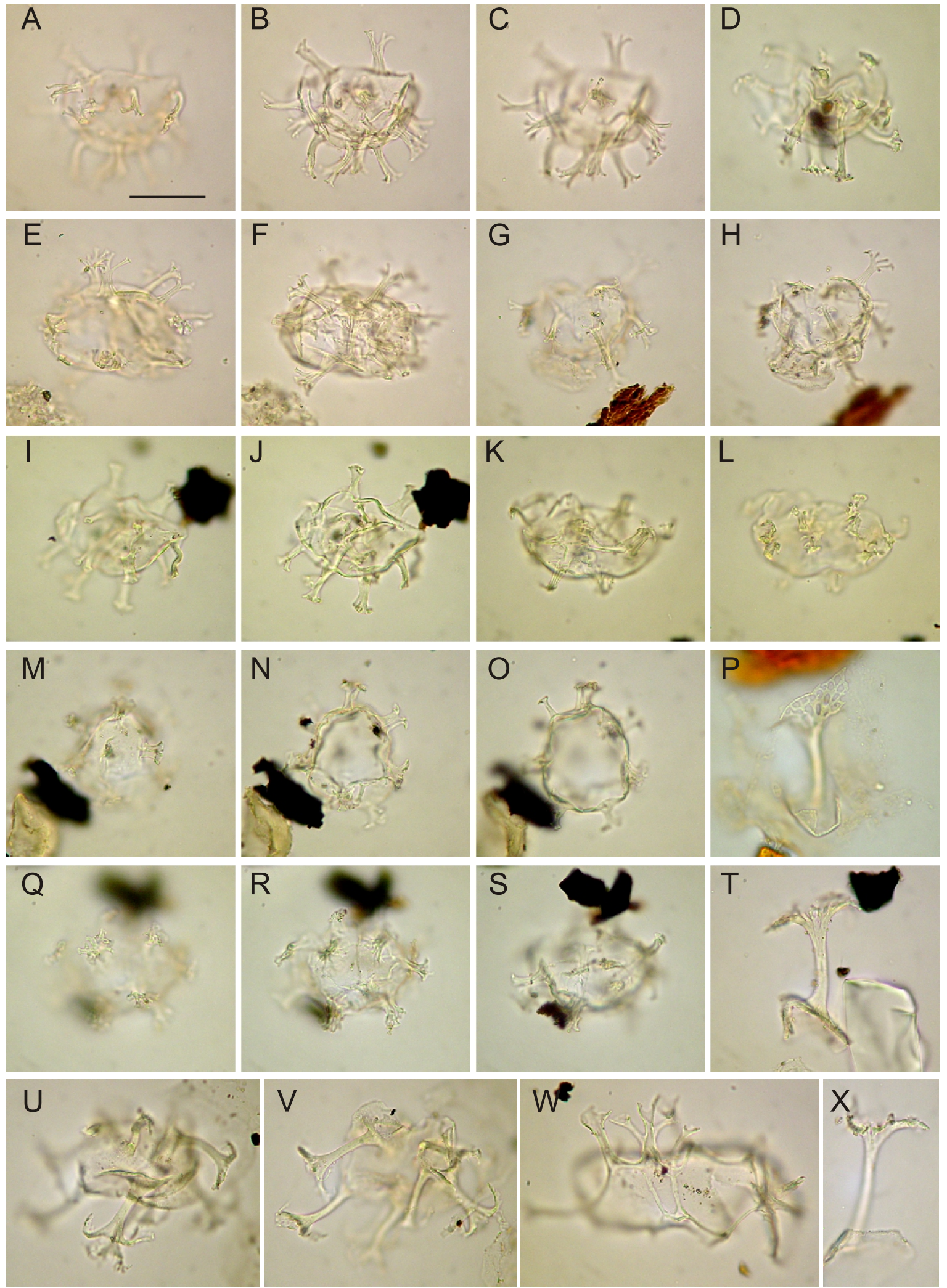

Fig. 5. Dinoflagellate cysts from sandy deposits at Lipowiec (scale bar $=25 \mu \mathrm{m}$ )

A-C - Homotryblium floripes (150 cm); D - Homotryblium plectilum $(380 \mathrm{~cm}) ; \mathbf{E}, \mathbf{F}-$ Homotryblium floripes $(150 \mathrm{~cm}) ; \mathbf{G}, \mathbf{H}$ Homotryblium floripes $(380 \mathrm{~cm})$; I, J - Homotryblium plectilum $(220 \mathrm{~cm}) ; \mathbf{K}, \mathbf{L}-$ Homotryblium vallum $(220 \mathrm{~cm})$; $\mathbf{M}-\mathbf{O}-$ Homotryblium vallum $(360 \mathrm{~cm}) ; \mathbf{P}$ - Areosphaeridium diktyoplokum: isolated paraplate with a process terminated with a characteristic platform (2/2015); Q-S - Homotryblium vallum $(360 \mathrm{~cm}) ; \mathbf{T}$ - isolated process, presumably of Areosphaeridium michoudii $(380 \mathrm{~cm}) ; \mathbf{U}, \mathbf{V}$ - Areosphaeridium michoudii $(380 \mathrm{~cm}) ; \mathbf{W}$-incomplete specimen of Spiniferites pseudofurcatus $(380 \mathrm{~cm}) ; \mathbf{X}$ - isolated process, presumably of Areosphaeridium michoudii $(380 \mathrm{~cm})$ 

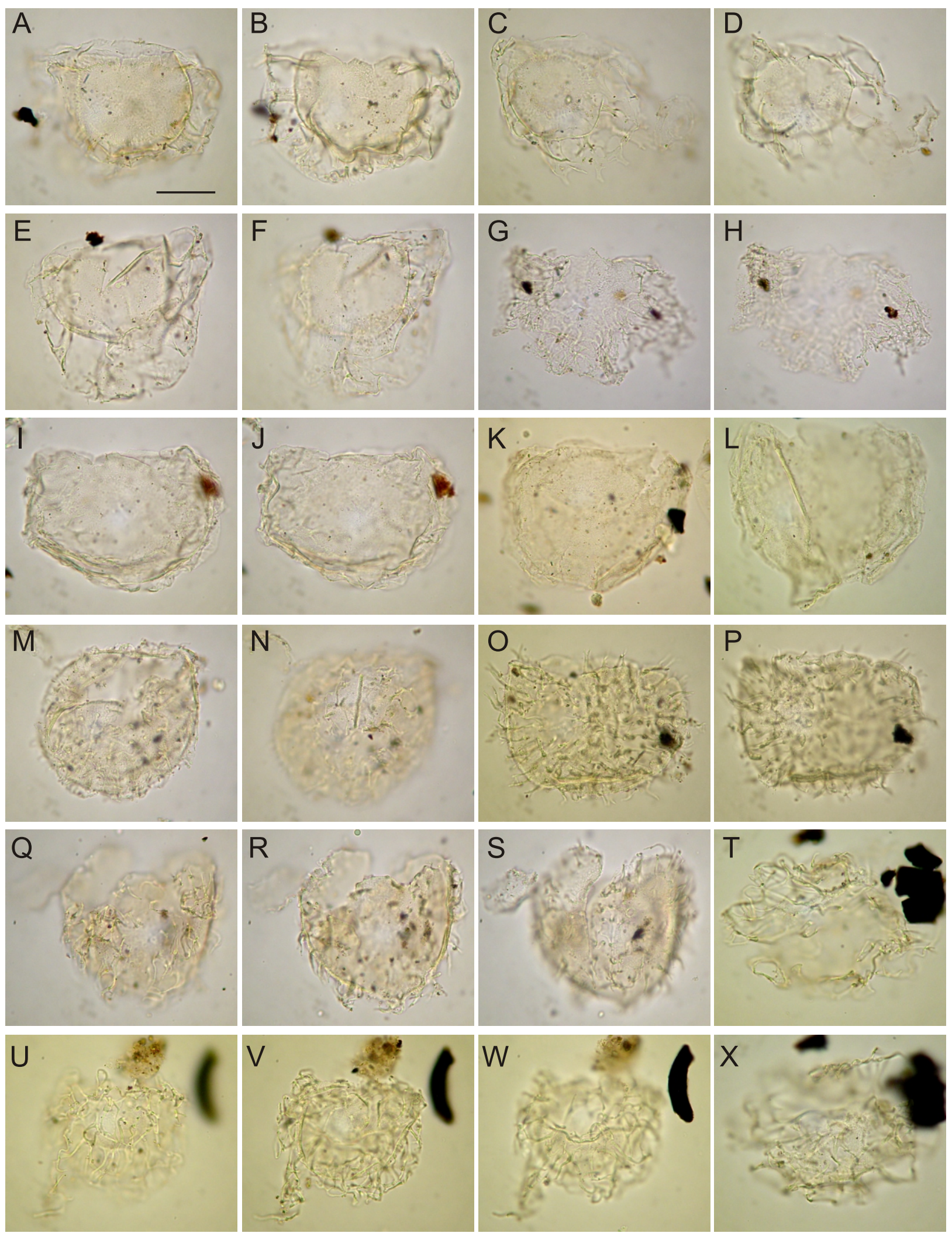

Fig. 6. Dinoflagellate cysts from sandy deposits at Lipowiec (scale bar $=25 \mu \mathrm{m}$ )

A, B - Glaphyrocysta sp. (380 cm); C, D - Glaphyrocysta semitecta $(380 \mathrm{~cm}) ; \mathbf{E}, \mathbf{F}-$ Glaphyrocysta cf. semitecta $(380 \mathrm{~cm}) ; \mathbf{G}, \mathbf{H}-$ Glaphyrocysta microfenestrata (sample 2/2015); I, J - Membranophoridium connectum $(380 \mathrm{~cm})$; K - Membranophoridium connectum $(220 \mathrm{~cm})$; L - Membranophoridium aspinatum $(220 \mathrm{~cm}) ; \mathbf{M}, \mathbf{N}$ - Heterosphaeridium sp. A sensu Gedl, $2013(380 \mathrm{~cm}) ; \mathbf{O}$, P - Heterosphaeridium sp. A sensu Gedl, $2013(380 \mathrm{~cm}) ; \mathbf{Q}-\mathbf{S}$ - Heterosphaeridium sp. A sensu Gedl, $2013(380 \mathrm{~cm}) ; \mathbf{T}, \mathbf{X}-$ Adnatosphaeridium multispinosum $(220 \mathrm{~cm}) ; \mathbf{U}-\mathbf{W}$ - Adnatosphaeridium multispinosum $(380 \mathrm{~cm})$ 

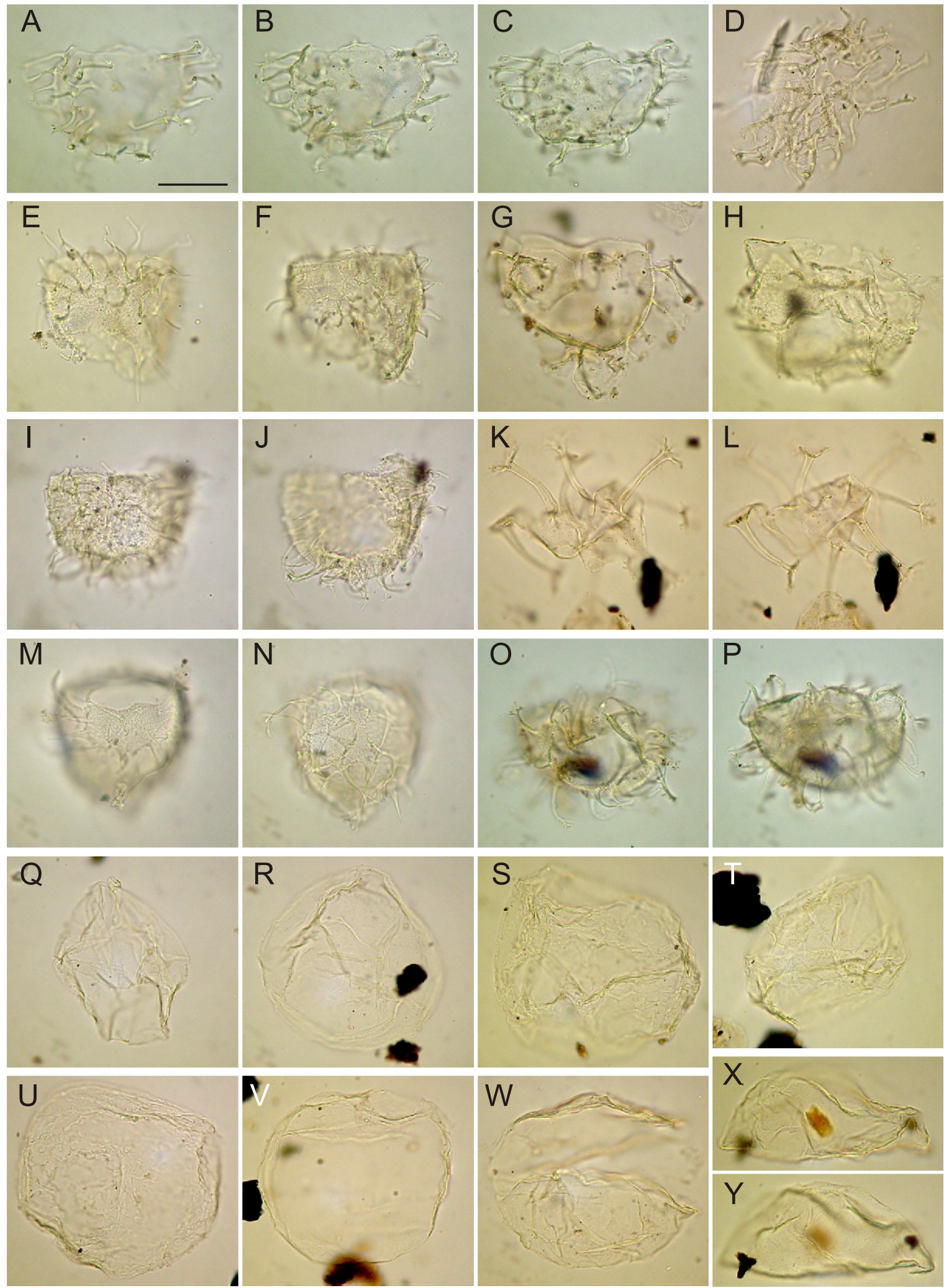

Fig. 7. Dinoflagellate cysts from sandy deposits at Lipowiec (scale bar $=25 \mu \mathrm{m}$ )

A-C - Cleistosphaeridium sp. A sensu Gedl, $2013(380 \mathrm{~cm})$; D - Cleistosphaeridium sp. A sensu Gedl, 2013: a wrinkled specimen showing granular structure of the cyst wall $(380 \mathrm{~cm}) ; \mathbf{E}, \mathbf{F}-$ Cleistosphaeridium cf. placacanthum $(380 \mathrm{~cm}) ; \mathbf{G}-$ Glaphyrocysta sp. $(380 \mathrm{~cm}) ; \mathbf{H}-$ Pentadinium? sp.: specimen with thick and granular endocyst $(380 \mathrm{~cm}) ; \mathbf{I}, \mathbf{J}-$ Cleistosphaeridium cf. placacanthum sp. $(380 \mathrm{~cm}) ; \mathbf{K}, \mathbf{L}-$ Homotryblium aculeatum $(220 \mathrm{~cm}) ; \mathbf{M}, \mathbf{N}$ - Cleistosphaeridium placacanthum (150 cm); O, P - Cleistosphaeridium placacanthum (2/2015); Q-Y - spherical thin-walled palynomorphs (all $220 \mathrm{~cm}$ ) 
nophoridium, which are most frequent in the sample from $380 \mathrm{~cm}$ depth. The sample from $220 \mathrm{~cm}$ depth is characterized by the frequent occurrence of thin-walled proximate forms of uncertain origin (Fig. 7Q-Y). Most of these are smooth, bi-layered; none has a pylome. Some show a girdle in equatorial position, along which a split is observed in some specimens (Fig. $7 \mathrm{~W})$. This split leads to a complete separation of two equal halves (Fig. 7X, Y). This feature resembles epicystal dinoflagellate cysts such as Mendicodinium, but in the case of the Lipowiec specimens no typical dinoflagellate plate arrangement (e.g., a sulcal notch) was observed.

\section{INTERPRETATION}

\section{BIOSTRATIGRAPHY}

Miocene strata of the Polish part of Roztocze have so far yielded relatively infrequent dinoflagellate cysts. This is due to sedimentary conditions specific for this area, which include shallow-marine, high-energy conditions (e.g., Wysocka, 2002) that were presumably hostile for dinoflagellates and/or for their preservation. Most of the coarse-grained, commonly organodetrital rocks that build Roztocze are barren. Dinoflagellate cyst assemblages are found in infrequent fine-grained layers; they consist there of a mixture of reworked Eocene species, and ones believed to be in situ. The similar state of preservation makes separating these two groups difficult in the case of long-ranging species. The assemblages described from Lipowiec consist almost exclusively of species that appeared for the last time before the Middle Miocene. A short overview of their ranges is given below:

- Adnatosphaeridium multispinosum: Early-Late Eocene (Powell, 1992), Early-Middle Eocene (Stover et al., 1996), Eocene-Early Oligocene (Köthe and Piesker, 2007), Middle Eocene (Vasilyeva, 2013);

- Areosphaeridium diktyoplokum: latest Early-Late Eocene (Powell, 1992), Early-Late Eocene (Stover et al., 1996; Köthe and Piesker, 2007); the last appearance of this species is reported from the Eocene/Oligocene boundary interval (see Eldrett et al., 2004, for discussion);

- Areosphaeridium michoudii: Early Eocene (Vasilyeva, 2013); last appearance: Middle Priabonian (Bujak and Mudge, 1994; Mudge and Bujak, 1994; Eldrett et al., 2004); Late Priabonian (Heilmann-Clausen and van Simaeys, 2005; Thomsen et al., 2012);

- Enneadocysta sp.: Middle Eocene-Early Oligocene (Stover et al., 1996 as the Enneadocysta arcuata "complex"; Köthe and Piesker, 2007 as Enneadocysta spp.);

- Glaphyrocysta microfenestrata: latest Middle Eocene-earliest Oligocene (Powell, 1992), Early Oligocene: Köthe and Piesker, 2007);

- Glaphyrocysta semitecta: Bartonian-Rupelian (De Coninck, 1995); Lutetian-Rupelian (Heilmann-Clausen and van Simaeys, 2005), Bartonian-Priabonian (Vasilyeva, 2013); a total range of $G$. semitecta in Northern Hemisphere mid-latitudes: latest Lutetian-Early Rupelian (Williams et al., 2004); last appearance: earliest Rupelian (Mudge and Bujak, 1994);

- Membranophoridium aspinatum: Middle Eocene-Oligocene (Powell, 1992), Late Eocene-Early Oligocene (De Coninck, 1995), Late Eocene-Oligocene (Stover et al., 1996); Priabonian (Heilmann-Clausen and van Sima- eys, 2005); Munsterman and Brinkhuis (2004) report the

highest occurrence of this species from uppermost Chattian-Lower Aquitanian of the North Sea.

A Paleogene, most likely Eocene age can be referred to the species Cleistosphaeridium sp. A and Heterosphaeridium sp. $A$, both described by the author from the Eocene Popiele Beds (Gedl, 2013).

Precise dating of the dinoflagellate cyst assemblages in question is enabled by Homotryblium floripes, and the morphologically similar $H$. plectilum and $H$. vallum, which are most frequent in the material studied. Being widely distributed in Paleogene and Early Miocene strata, the occurrence of Homotryblium occurrence in the Middle and Upper Miocene is less evident. Dybkjær and Piasecki (2010) reported an acme of Homotryblium (including $H$. plectilum and $H$. tenuispinosum) from the uppermost Oligocene-lowermost Miocene of the North Sea. A similar acme of Homotryblium floripes/plectilum was reported by Munsterman and Brinkhuis (2004) from the coeval interval of the North Sea Miocene. The same authors reported the highest occurrence of Homotryblium vallum in the Lower Miocene of the North Sea (uppermost Aquitanian-lowermost Burdigalian). A similar age of this event is given by de Verteuil and Norris (1996). Stover et al. (1996) show a Lower Miocene highest occurrence of $H$. plectilum and $H$. vallum in northwestern Europe and offshore eastern North America. Powell (1986) reports a Chattian last appearance of $H$. plectilum and Aquitanian last appearance of $H$. floripes in NW Italy. According to Williams et al. (1993) both $H$. floripes and $H$. vallum appeared for the last time in North Atlantic in late Early Miocene. Several authors (e.g., Wrenn and Kokinos, 1986; Dybkjær and Piasecki, 2010) reported the occurrence of Homotryblium in the Upper Miocene or even younger strata, but according to de Verteuil and Norris (1996: p. 20, 22; see this publication for full reference list and discussion) these records are presumably the result of reworking.

First appearance data of the Homotryblium floripes complex show that these species appeared for the first time in the Eocene, mainly during the Late Eocene. Williams et al. (2004) report a total range of $H$. floripes from equatorial areas as Lutetian-Late Miocene, but in higher latitudes its oldest occurrences are known from the Priabonian (Heilmann-Clausen and van Simaeys, 2005; Vasilyeva, 2013) and Bartonian-?Priabonian (Gedl, 2014, 2015). H. vallum, in turn, is known already from Eocene strata, e.g., uppermost Priabonian (Köthe and Piesker, 2007), and Bartonian-Priabonian (Gedl, 2013).

The distribution of Homotryblium in the Miocene of the Carpathian Foredeep Basin supports the thesis of de Verteuil and Norris (1996). This genus is missing in most Middle Miocene (Badenian) sections studied, and if present, it occurs as evidently reworked (poorly preserved from the Carpathian Paleogene; e.g., Gedl, 1999) or associated with other evidently reworked specimens (e.g., Gedl, 1999, 2005, 2016). Soliman and Piller (2007), who studied the Karpatian/Badenian boundary interval in the Styrian Basin in Austria, noted the rare occurrence of Homotryblium sp. in Karpatian strata only; Badenian strata, devoid of reworked Paleogene forms, contained no Homotryblium.

The species with the longest stratigraphic ranges among those found in the samples studied are Cleistosphaeridium placacanthum - Middle Eocene to Late Miocene (e.g., Eaton et al., 2001) and Spiniferites pseudofurcatus - Cretaceous-Middle Miocene (e.g., Stover et al., 1996). Both species could thus be in situ. They have been encountered as in situ forms in the Upper Badenian of Polish Roztocze, where they co-occur with Eocene species (Gedl, 2016). They are also known from coeval strata of the Ukrainian part of the Carpathian Foredeep Basin, 
where they occur in assemblages devoid of reworked specimens (Gedl and Peryt, 2011) or they are associated with rare reworked Paleogene specimens (Peryt et al., 2014).

This overview of stratigraphic ranges suggests that dinoflagellate cyst assemblages from Lipowiec are of Late Eocene age. The question of whether $C$. placacanthum and S. pseudofurcatus are in situ or they are reworked remains unsolved; the lack of any other Miocene species, like those from younger strata of Roztocze (e.g., Polysphaeridium), suggests that they are also reworked.

\section{PALAEOENVIRONMENT}

The lack of Miocene dinoflagellate cysts in the deposits studied points to a restricted sedimentary setting. Too little data is available for a precise environmental reconstruction, but the most likely factor hostile for dinoflagellates and/or their preservation was the very shallow water and high-energy hydrodynamic conditions. The latter, easily visible in sedimentary structures (e.g., Jankowski and Margielewski, 2014), may be responsible for the lack of dinoflagellate cysts. During periods of calmer deposition, clay layers accumulated. They yielded reworked specimens only; the lack of in situ taxa shows that environmental conditions were still not favourable for dinoflagellates. The presence of incertae sedis forms (spherical palynomorphs) in the sample from $220 \mathrm{~cm}$ depth, possibly in situ, may be related to these specific sedimentary conditions, but so long as their palaeoenvironmental preferences are unknown, nothing more can be suggested.

Reworked dinoflagellate cysts can be much more useful, representing the only palaeontological trace of eroded Eocene strata. Although their assemblages may be incomplete due to selective erosion and/or re-accumulation processes, on their basis an attempt of Late Eocene Roztocze environment reconstruction can be undertaken.

The presence of marine assemblages shows that this part of Rozotcze was also flooded by a marine transgression during the Late Eocene. The lack of offshore species such as Impagidinium (e.g., Wall et al., 1977; Harland, 1983; Edwards and Andrle, 1992; Brinkhuis, 1994; Rochon et al., 1999; Boessenkool et al., 2001) and Nematosphaeropsis (Brinkhuis, 1994; Dale, 1996; Rochon et al., 1999) suggests a near-shore, proximal marine setting. This interpretation is supported by frequent occurrences of Homotryblium. This genus is widely associated with near-shore, littoral environments, commonly with increased salinity (e.g., Köthe, 1990; Brinkhuis, 1994). The latter feature may indicate slightly increased salinity of the marine waters, although Dybkjær (2004) suggested that Homotryblium may also benefit from decreased salinity conditions.

Another characteristic feature of the Lipowiec assemblages is a lack of peridinioids, which are mainly heterotrophs and thrive in waters with increased nutrient availability (e.g., deltaic or upwelling waters; see e.g., Biffi and Grignani, 1983; Brinkhuis, 1994; Sprangers et al., 2004; Sluijs et al., 2005). Their lack may thus reflect oligotrophic conditions. This reconstruction is supported by a lack of Lingulodinium machaerophorum, an autotroph, which is commonly associated with eutrophic proximal waters (e.g., Targarona et al., 1999; Boessenkool et al., 2001).

All these features suggest that dinoflagellate cysts found in sands at Lipowiec inhabited a near shore, presumably shallow marine setting with rather oligotrophic waters with slightly increased salinity. Therefore, a lagoonal embayment can be reconstructed for this part of Roztocze during the Late Eocene.

\section{DISCUSSION}

This is the first report of dinoflagellate cyst occurrence in the basal part of the Middle Miocene (Badenian) succession in this part of Roztocze. Attempts to search for dinoflagellate cysts in coeval deposits undertaken by the author during the last few years have proved fruitless: quartz sands exposed at Gleboviti and Stradc (Ukrainian part of Roztocze; see Wysocka and Roniewicz, 2004: fig. 3 for correlation) were found to be barren. Data presented in this and previous papers show that during the Badenian transgression in the Polish part of Roztocze intense erosion of marine Eocene strata took place. Clay layers within Upper Badenian organodetrital limestone in the vicinity of Józefów yielded frequent Middle and Late Eocene dinoflagellate cysts (Gedl, 2012). Jankowski et al. (2014) reported calcareous nannoplankton typical of the NP 17 Zone (Bartonian) from clays overlying Miocene brown-coal deposits in Siedliska.

The Lipowiec dinoflagellate cyst assemblages show qualitative and quantitative similarities to the reworked assemblages from Józefów in the frequent occurrence of Homotryblium floripes complex representatives (Gedl, 2016). Three samples collected from the Józefów quarries yielded the following proportions of $H$. floripes plus $H$. plectilum and $H$. vallum (calculated for reworked forms only): $49 \%$ (sample Pds-1), 55\% (Pds-2), and $30 \%$ (Jzf-3). High proportions of Homotryblium and a simultaneous lack of peridinioids suggest that during both the Early and Late Badenian similar lagoonal Eocene settings were gradually washed out in this part of Roztocze. The lower proportion of Homotryblium in the Upper Badenian samples, associated with a higher number of taxa such as Areosphaeridium michoudii, Areoligera spp., and Batiacasphaera ?compta (gen. et spec. indet. sensu Gedl, 2013), may indicate a gradual erosion of the Eocene succession in Roztocze, and their subsequent inverted accumulation during the Badenian. During the Early Badenian the top of the Priabonian succession underwent erosion (and hence the youngest assemblages composed almost entirely of Homotryblium were washed out and accumulated); during the Late Badenian, in turn, erosion reached the base of the Eocene succession (Bartonian-?Priabonian), and older assemblages with less common Homotryblium were eroded. Acceptance of this scenario suggests that the original Eocene succession in this part of Roztocze accumulated in a gradually shallowing marine environment, gradually transforming to a lagoonal embayment, reflected by the increasing proportion of Homotryblium.

Reworked dinoflagellate cysts from Lipowiec show some taxonomic similarities (particularly when Homotryblium floripes complex representatives are considered) to Eocene assemblages that occur in situ at Roztocze. An assemblage with common Homotryblium floripes, dated to the latest Bartonian?-Early Priabonian, was described by the author from the top of the Eocene succession of the Sołokija Graben in Roztocze; on the base of its composition, a very shallow marine, presumably partly restricted setting was reconstructed (Gedl, 2014). The Homotryblium floripes-dominated Sołokija assemblages differ, however, by the co-occurrence of peridinioids and Lingulodinium machaerophorum, which are missing in material from Lipowiec. Moreover, strata from the top of the Sołokija, which contain these assemblages, are separated by layers that yielded almost monospecific Deflandrea assemblages.

The occurrence of peridinioids is also typical of the Priabonian succession in the Carpathian Foredeep (Łukowa-4 borehole); rare specimens of Lingulodinium machaerophorum have been found there (Gedl, 2015). Although these strata 
yielded frequent specimens of Homotryblium too, in this case they represent $H$. aculeatum; $H$. floripes is rare there.

Homotryblium plectilum, in turn, is a common species in Priabonian dark mudstones of the Popiele Beds at Koniusza (Gedl, 2013). The sedimentary setting of these mudstones was interpreted as a marginal, proximal, near-shore zone of the Carpathian sea. Also in this case, peridinioids (mainly Deflandrea), although subordinate, occur as an important part of dinoflagellate cyst assemblages (Gedl, 2013: figs. 13 and 14).

The comparison presented above shows that the Lipowiec assemblages are notable for the lack of peridinioids and Lingulodinium machaerophorum. The other assemblages from coeval strata, although also including frequent Homotryblium, contain peridinioids and $L$. machaerophorum. Occurrences of the two latter species presumably reflect slightly higher availability of nutrients, possibly caused by a higher influx of freshwater. This is clearly visible, particularly in case of the Sołokija succession, where levels with Homotryblium are interlayered with levels with monospecific Deflandrea assemblages, likely reflecting brackish conditions.

The assemblages from Lipowiec are thus presumably further traces of Late Eocene near-shore marine settings that surrounded the emerged areas to the north of the present day Lublin Upland; to the south they passed into the deep marine basins of the Carpathian sea. These settings were characterized by frequent palaeoenvironmental changes, typical of shallow-marine, proximal marine environments, where lagoonal, tidal, deltaic and other sedimentological settings commonly replaced or interfingered with each other. The Lipowiec assemblages presumably reflect lagoonal oligotrophic environments, whereas coeval assemblages from neighbouring areas inhabited settings influenced by freshwater influx.

\section{CONCLUSIONS}

1. The sandy succession that occurs in basal parts of the Miocene at Roztocze usually contains no fossils and its stratigraphic position is based on superposition (Musiał, 1987). The results presented in this paper are the first documentation of their dinoflagellate cyst content. Their assemblages, however, are reworked.

2. Lack of Miocene dinoflagellate cysts in deposits studied suggests that environmental conditions during early stages of the Badenian transgression at Roztocze were unfavourable for dinoflagellates and/or inappropriate for their preservation (e.g., high energetic hydrodynamic conditions during coarse grain fraction accumulation).

3. The discovery of reworked Eocene dinoflagellate cysts in the Lower Badenian, the basal part of succession, as described in this paper, shows that erosion of the marine Paleogene cover started simultaneously with the Badenian transgression.

4. The taxonomic composition of the reworked assemblages shows that they were washed out from near-shore, shallow-water Upper Eocene deposits accumulated presumably in a lagoonal embayment characterized by oligotrophic high-salinity waters. Erosion of similar deposits, although presumably slightly older, lasted also during the Late Badenian when organodetrital carbonate deposits accumulated in this part of Roztocze.

5. Comparison of the Lipowiec assemblages with Late Eocene dinoflagellate cyst assemblages from other sites at Roztocze and the Carpathian foreland shows that the latter, although also shallow-marine and partly lagoonal, accumulated in slightly different environments. Lack of taxa that benefited from high concentration of nutrients in marine waters, such as peridinioids and Lingulodinium machaerophorum, suggest oligotrophic conditions in the case of Lipowiec. The occurrence of both peridinioids and $L$. machaerophorum (in various proportions) at other sites shows that these areas were influenced, to a certain degree, by freshwater influx in the Late Eocene.

Acknowledgements. I would like to thank A. Wysocka (University of Warsaw) for telling me about the exposure of glauconitic sand at Lipowiec. W. Margielewski (Polish Academy of Sciences, Kraków) is acknowledged for valuable comments and discussion while preparing this manuscript. B. Słodkowska (Polish Geological Institute - National Research Institute, Warszawa), S. De Schepper (University of Bergen) and an anonymous reviewer are kindly acknowledged for their critical remarks on the manuscript.

\section{SPECIES LIST}

(taxonomy and citations follow Fensome et al., 2008):

Adnatosphaeridium multispinosum Williams et Downie, 1966

Areosphaeridium diktyoplokum (Klumpp, 1953) Eaton, 1971

?Areosphaeridium michoudii Bujak, 1994

Cleistosphaeridium placacanthum (Deflandre et Cookson, 1955) Eaton et al., 2001

Cleistosphaeridium cf. placacanthum (Deflandre et Cookson, 1955) Eaton et al., 2001

Cleistosphaeridium sp. A sensu Gedl, 2013

Enneadocysta sp.

Glaphyrocysta microfenestrata (Bujak, 1976) Stover et Evitt, 1978

Glaphyrocysta semitecta (Bujak, 1980) Lentin et Williams, 1981

Glaphyrocysta cf. semitecta (Bujak, 1980) Lentin et Williams, 1981

Glaphyrocysta sp.

Heterosphaeridium sp. A sensu Gedl, 2013

Homotryblium aculeatum Williams, 1978

Homotryblium floripes (Deflandre et Cookson, 1955) Stover, 1975

Homotryblium plectilum Drugg et Loeblich Jr., 1967

Homotryblium vallum Stover, 1977

Membranophoridium aspinatum Gerlach, 1961

Membranophoridium connectum Stover et Hardenbol, 1994

Pentadinium? sp.

Spiniferites pseudofurcatus (Klumpp, 1953) Sarjeant, 1970 


\section{REFERENCES}

Biffi, U., Grignani, D., 1983. Peridinioid dinoflagellate cysts from the Oligocene of the Niger Delta, Nigeria. Micropaleontology, 29: $126-145$

Boessenkool, K.P., van Gelder, M.J., Brinkhuis, H., Troelstra, S.R., 2001. Distribution of organic-walled dinoflagellate cysts in surface sediments from transects across the Polar Front offshore southeast Greenland. Journal of Quaternary Science, 16: 661-666.

Brinkhuis, H., 1994. Late Eocene to Early Oligocene dinoflagellate cysts from the Priabonian type-area (northeast Italy): biostratigraphy and palaeoenvironmental interpretation. Palaeogeography, Palaeoclimatology, Palaeoecology, 107: 121-163.

Bujak, J., Mudge, D., 1994. A high-resolution North Sea Eocene dinocyst zonation. Journal of the Geological Society, 151: 449-462.

Buraczyński, J., Krzowski, Z., 1994. Middle Eocene in the Sołokija Graben on Roztocze Upland. Geological Quarterly, 38 (4): 739-753.

Czepiec, I., 1996. Biostratygrafia i warunki depozycji osadów północnej strefy brzeżnej sarmatu Polski (in Polish). Geologia AGH, 22: 309-337.

Dale, B., 1996. Dinoflagellate cyst ecology: modelling and geological applications. In: Palynology: principles and applications (eds. J. Jansonius and D.C. McGregor). American Association of Stratigraphic Palynologists Foundation, Dallas, Texas, 3: 1249-1275

De Coninck, J., 1995. Microfossiles à paroi organique du Bartonien, Priabonien et Rupélien inférieur dans le sondage de kallo; espèces significatives dans les sondages de Woensdrecht, Kallo et Mol. Mededelingen Rijks Geologische Dienst, 53: 65-105.

de Verteuil, L., Norris, G., 1996. Miocene dinoflagellate stratigraphy and systematics of Maryland and Virginia. Micropaleontology, 42 (Supplement).

Dybkjær, K., 2004. Morphological and abundance variations in Homotryblium-cyst assemblages related to depositional environments; uppermost Oligocene-Lower Miocene, Jylland, Denmark. Palaeogeography, Palaeoclimatology, Palaeoecology, 206: 41-58.

Dybkjær, K., Piasecki, S., 2010. A Neogene dinocyst zonation for the eastern North Sea Basin, Denmark. Review of Palaeobotany and Palynology, 161: 1-29.

Eaton, G.L., Fensome, R.A., Riding, J.B., Williams, G.L., 2001 Re-evaluation of the status of the dinoflagellate cyst genus Cleistosphaeridium. Neues Jahrbuch für Geologie und Paläontologie, Abhandlungen, 219: 171-205.

Edwards, L.E., Andrle, V.A.S., 1992. Distribution of selected dinoflagellate cysts in modern marine sediments. In: Neogene and Quaternary Dinoflagellate Cysts and Acritarchs (eds. M.J. Head and J.H. Wrenn): 259-288. American Association of Stratigraphic Palynologists Foundation.

Eldrett, J.S., Harding, I.C., Firth, J.V., Roberts, A.P., 2004. Magnetostratigraphic calibration of Eocene-Oligocene dinoflagellate cyst biostratigraphy from the Norwegian-Greenland Sea. Marine Geology, 204: 91-127.

Fensome, R.A., MacRae, R.A., Williams, G.L., 2008. DINOFLAJ2, Version 1. American Association of Stratigraphic Palynologists, Data Series, 1.

Garecka, M., Jugowiec, M., 1999. Results of biostratigraphic study of Miocene in the Carpathian Foredeep based on calcareous nannoplankton (in Polish with English summary). Prace Państwowego Instytutu Geologicznego, 168: 29-41.

Garecka, M., Marciniec, P., Olszewska, B., Wójcik, A., 1996. New biostratigraphic data and attempt to correlation of the Miocene deposits in the basement of the Western Carpathians (in Polish with English summary). Przegląd Geologiczny, 44: 495-501.

Gaździcka, E., 1994. Middle Eocene calcareous nannofossils from the Roztocze region (SE Poland) - their biostratigraphic and palaeogeographic significance. Geological Quarterly, 38 (4): 727-734.
Gedl, P., 1999. Palaeoenvironmental and sedimentological interpretations of the palynofacies analysis of the Miocene deposits from the Jamnica S-119 borehole (Carpathian Foredeep, Poland). Geological Quarterly, 43 (4): 479-492.

Gedl, P., 2000. Newly found marine Oligocene deposits in the Carpathian Foreland and its palaeogeographic consequences. Slovak Geological Magazine, 6: 155-157.

Gedl, P., 2005. In situ and recycled dinoflagellate cysts from Middle Miocene deposits at Beczyn, Carpathian Foredeep, Poland. Studia Geologica Polonica, 124: 371-394.

Gedl, P., 2012. Reworked Eocene-Oligocene dinoflagellate cysts in the Miocene of the Carpathian Foredeep Basin: implications for Paleogene palaeogeography in SE Poland. Geological Quarterly, 56 (4): 853-868.

GedI, P., 2013. Eocene dinoflagellate cysts from the Popiele beds at Koniusza (Skole Nappe, Flysch Carpathians, Poland): taxonomy, biostratigraphy, and palaeoenvironmental reconstruction of a marginal marine basin. Studia Geologica Polonica, 136

GedI, P., 2014. Eocene dinoflagellate cysts from the Sołokija Graben (Roztocze, SE Poland): biostratigraphy and palaeoenvironment. Geological Quarterly, 58 (4): 707-728.

Gedl, P., 2015. Dinoflagellate cysts from the Palaeogene of the Łukowa-4 borehole (Carpathian Foredeep, SE Poland): biostratigraphy and palaeoenvironment. Annales Societatis Geologorum Poloniae, 85: 285-308.

Gedl, P., 2016. Dinoflagellate cysts and palynofacies from the upper Badenian (Middle Miocene) of the Roztocze area at Józefów and Żelebsko (Carpathian Foredeep Basin, Poland): palaeoenvironmental implications. Annales Societatis Geologorum Poloniae, 86, doi: http://dx.doi.org/10.14241/asgp.2016.010

Gedl, P., Peryt, D., 2011. Dinoflagellate cyst, palynofacies and foraminiferal records of environmental changes related to the Late Badenian (Middle Miocene) transgression at Kudryntsi (western Ukraine). Annales Societatis Geologorum Poloniae, 81: 331-349.

Harland, R., 1983. Distribution maps of recent dinoflagellate cysts in bottom sediments from the North Atlantic Ocean and adjacent seas. Palaeontology, 26: 321-387.

Heilmann-Clausen, C., van Simaeys, S., 2005. Dinoflagellate cysts from the Middle Eocene to ?lowermost Oligocene succession in the Kysing research borehole, central Danish Basin. Palynology, 29: 141-204.

Jankowski, L., Margielewski, W., 2014. Stop 1.1. Lipowiec. Profil utworów piaszczystych miocenu (in Polish). In: V Warsztaty Geomorfologii Strukturalnej, Strukturalne i litofacjalne uwarunkowania rozwoju rzeźby Roztocza w aspekcie historii tektoniczno-basenowej Karpat i zapadliska przedkarpackiego, Zwierzyniec - Józefów - Horyniec, 24-26.09.2014 r. (eds. W. Margielewski, J. Urban, L. Jankowski and K. Buczek): 45-48. Instytut Ochrony Przyrody PAN, Kraków-Zwierzyniec.

Jankowski, L., Margielewski, W., 2015. Tectonic position of the Roztocze region in the light of the evolution history of the Carpathian Foredeep (in Polish with English summary). Biuletyn Państwowego Instytutu Geologicznego, 462: 7-28.

Jankowski, L., Margielewski, W., Krapiec, M., 2014. Stop 3.4 Siedliska. Profil utworów karpatu z burowęglem (wiercenie) (in Polish). In: V Warsztaty Geomorfologii Strukturalnej, Strukturalne i litofacjalne uwarunkowania rozwoju rzeźby Roztocza w aspekcie historii tektoniczno-basenowej Karpat i zapadliska przedkarpackiego, Zwierzyniec-Józefów-Horyniec, 24-26.09.2014 r (eds. W. Margielewski, J. Urban, L. Jankowski and K. Buczek): 93-95. Instytut Ochrony Przyrody PAN, Kraków-Zwierzyniec.

Köthe, A., 1990. Paleogene dinoflagellates from northwest Germany. Geologisches Jahrbuch, R. A, 118: 1-111.

Köthe, A., Piesker, B., 2007. Stratigraphic distribution of Paleogene and Miocene dinocysts in Germany. Révue de Paléobiologie, 26: 1-39.

Kotlarczyk, J., 1985. An outline of the stratigraphy of marginal tectonic units of the Carpathian orogene in the Rzeszów-Przemyśl area. 
In: Geotraverse Kraków-Baranów-Rzeszów-Przemyśl-Komańcza-Dukla. Guide to Excursion 4 (ed. J. Kotlarczyk): 21-32. XIII Congress Carpathian-Balkan Geological Association, Kraków, Poland. Geological Institute, Kraków.

Krąpiec, M., Jankowski, L., Margielewski, W., Krąpiec, P., 2010. Roztoczański Park Narodowy (in Polish). Mapa geologiczno-turystyczna. Państwowy Instytut Geologiczny, Warszawa.

Mudge, D.C., Bujak, J.P., 1994. Eocene stratigraphy of the North Sea basin. Marine and Petroleum Geology, 11: 166-181.

Munsterman, D.K., Brinkhuis, H., 2004. A southern North Sea Miocene dinoflagellate cyst zonation. Netherlands Journal of Geosciences/Geologie en Mijnbouw, 83: 267-285.

Musiał, T., 1987. Miocene of Roztocze (south-eastern Poland) (in Polish with English summary). Biuletyn Geologiczny, 31: 5-149.

Myśliwiec, M., Śmist, P., 2006. Eocene and Oligocene sediments of the Tarnogród area (NE part of the Polish Carpathian Foredeep) (in Polish with English summary). Przegląd Geologiczny, 54: 724-730.

Ney, R., Burzewski, W., Bachleda, T., Górecki, W., Jakóbczak, K., Słupczyński, K., 1974. Outline of paleogeography and evolution of lithology and facies of Miocene layers in the Carpathian Foredeep (in Polish with English summary). Prace Geologiczne, 82: $1-65$.

Olszewska, B., 1999. Biostratigraphy of Neogene in the Carpathian Foredeep in the light of new micropalaeontological data (in Polish with English summary). Prace Państwowego Instytutu Geologicznego, 168: 9-27.

Oszczypko, N., 1996. The Miocene dynamics of the Carpathian Foredeep in Poland (in Polish with English summary). Przegląd Geologiczny, 44: 1007-1018.

Oszczypko, N., Krzywiec, P., Popadyuk, I., Peryt, T., 2006. Carpathian Foredeep Basin (Poland and Ukraine): its sedimentary, structural, and geodynamic evolution. AAPG Memoir, 84: 293-350.

Peryt, D., GedI, P., Peryt, T.M., 2014. Foraminiferal and palynological records of the Late Badenian (Middle Miocene) transgression in Podolia (Shchyrets near Lviv, western Ukraine). Geological Quarterly, 58 (3): 465-484.

Powell, A.J., 1986. Latest Palaeogene and earliest Neogene dinoflagellate cysts from the Lemme Section, northwest Italy. American Association of Stratigraphic Palynologists Contribution Series, 17: 83-104.

Powell, A.J., 1992. Dinoflagellate cysts of the Tertiary System. In: A Stratigraphic Index of Dinoflagellate Cysts (ed. A.J. Powell): 155-249. British Micropalaeontological Society Publication Series, Kluwer Academic Publishers.

Rochon, A., de Vernal, A., Turon, J.-L., Matthiessen, J., Head, M.J., 1999. Distribution of recent dinoflagellate cysts in surface sediments from the North Atlantic and adjacent seas in relation to sea-surface parameters. American Association of Stratigraphic Palynologists Contribution Series, 35: 1-146.

Sluijs, A., Pross, J., Brinkhuis, H., 2005. From greenhouse to icehouse; organic-walled dinoflagellate cysts as paleoenvironmental indicators in the Paleogene. Earth-Science Reviews, 68 : 281-315.

Soliman, A., Piller, W.E., 2007. Dinoflagellate cysts at the Karpatian/Badenian boundary of Wagna (Styrian Basin, Austria). Jahrbuch der Geologischen Bundesanstalt, 147: 405-417.
Sprangers, M., Dammers, N., Brinkhuis, H., van Weering, T.C.E., Lotter, A.F., 2004. Modern organic-walled dinofagellate cyst distribution offshore NW Iberia; tracing the upwelling system. Review of Palaeobotany and Palynology, 128: 97-106.

Stover, L.E., Brinkhuis, H., Damassa, S.P., de Verteuil, L., Helby, R.J., Monteil, E., Partridge, A.D., Powell, A.J., Riding, J.B., Smelror, M., Williams, G.L., 1996. Mesozoic-Tertiary dinoflagellates, acritarchs and prasinophytes. In: Palynology: principles and applications (eds. J. Jansonius and D.C. McGregor). American Association of Stratigraphic Palynologists Foundation, Dallas, Texas, 2: 641-750.

Szczechura, J., 1982. Middle Miocene foraminiferal biochronology and ecology of SE Poland. Acta Palaeontologica Polonica, 27: 3-45.

Targarona, J., Warnaar, J., Boessenkool, K.P., Brinkhuis, H., Canals, M., 1999. Recent dinoflagellate cyst distribution in the North Canary Basin, NW Africa. Grana, 38: 170-178.

Thomsen, E., Abrahamsen, N., Heilmann-Clausen, C., King, C., Nielsen, O.B., 2012. Middle Eocene to earliest Oligocene development in the eastern North Sea Basin: biostratigraphy, magnetostratigraphy and palaeoenvironment of the Kysing-4 borehole, Denmark. Palaeogeography, Palaeoclimatology, Palaeoecology, 350-352: 212-235.

Vasilyeva, O.N., 2013. Paleogene dinocysts from the Eastern Caspian Depression (the Uspenskaya SP-1 well, Kazakhstan). Litosphere, 1: 192-127.

Wall, D., Dale, B., Lohmann, G.P., Smith, W.K., 1977. The environmental and climatic distribution of dinoflagellate cysts in modern marine sediments from regions in the north and south Atlantic Oceans and adjacent seas. Marine Micropalaeontology, 2: 121-200.

Williams, G.L., Brinkhuis, H., Pearce, M.A., Fensome, R.A., Weegink, J.W., 2004. Southern Ocean and global dinoflagellate cyst events compared: index events for the Late Cretaceous-Neogene. Proceedings of the Ocean Drilling Project, Scientific Results, 189: 1-98.

Williams, G.L., Stover, L.E., Kidson, E.J., 1993. Morphology and stratigraphic ranges of selected Mesozoic-Cenozoic dinoflagellate taxa in the Northern Hemisphere. Geological Survey of Canada, Paper, 92-10: 1-137.

Wrenn, J.H., Kokinos, J.P., 1986. Preliminary comments on Miocene through Pleistocene dinoflagellate cysts from De Soto Canyon, Gulf of Mexico. American Association of Stratigraphic Palynologists Contribution Series, 17: 169-225.

Wysocka, A., 2002. Clastic Badenian deposits and sedimentary environments of the Roztocze Hills across the Polish-Ukrainian border. Acta Geologica Polonica, 52: 535-561.

Wysocka, A., Roniewicz, P., 2004. Representative geosites of the Roztocze Hills. Polish Geological Institute Special Papers, 13: 137-144.

Żytko, K., Gucik, S., Ryłko, W., Oszczypko, N., Zając, R., Garlicka, I., Nemčok, J., Eliáš, M., Menčik, E., Dvořák, J., Stránik, Z., Rakus, M., Matejovska, O., 1989. Geological map of the Western Outer Carpathians and their foreland without Quaternary formations, 1:500 000. In: Geological Atlas of the Western Outer Carpathians and their Foreland (eds. D. Poprawa and J. Nemčok). Państwowy Instytut Geologiczny, Warszawa. 